\title{
MIR124-2 wt Allele
}

National Cancer Institute

\section{Source}

National Cancer Institute. MIR124-2 wt Allele. NCI Thesaurus. Code C132888.

Human MIR124-2 wild-type allele is located in the vicinity of $8 q 12.3$ and is approximately 109 bases in leng th. This allele, which encodes MIR124-2 pre-miRNA, may play a role in neuronal differentiation. 